\title{
IDENTIFICATION OF PHYSICAL ACTIVITY AND BODY MASS INDEX ON THE INCIDENCE OF PREDIABETES MELLITUS IN HIGH SCHOOL STUDENTS
}

\author{
${ }^{1 *}$ Cahyo Wibowo, ${ }^{2}$ Venti Agustina, ${ }^{3}$ Suroto \\ Correspondence: Universitas Kristen Satya Wacana, Salatiga, Indonesiaa \\ E-mail: cahyo.wibowo@uksw.edu
}

\begin{abstract}
Prediabetes mellitus is a condition of a person's blood sugar, which, if in a fasting state, ranges from 100-125 mg / dL (IFG) or 2 hours after eating, the blood sugar level is 140-199 $\mathrm{mg} / \mathrm{dL}$. Physical activity and BMI are factors that trigger prediabetes mellitus. Therefore it is necessary to hold preventive efforts to reduce the rate of development of prediabetes mellitus which is increasing and increasing public awareness regarding the importance of maintaining a healthy lifestyle. The purpose of writing this literature is to analyze physical activity and body mass index on the incidence of prediabetes mellitus in high school students. The research writing method used a literature review. Data were collected from 30 journals which were then selected into 22 journals with related variables, namely physical activity and body mass index with the incidence of prediabetes mellitus, $a$ sample of high school students aged 15-18 years. The results of the literature review are that physical activity plays a role in controlling blood sugar and Body Mass Index (BMI) contributes to the occurrence of prediabetes if followed by an unhealthy waist circumference, less physical activity results in an increase in BMI which ultimately triggers prediabetes mellitus.
\end{abstract}

\section{Keywords: Physical Activity, BMI, Prediabetes Mellitus}

\section{Introduction}

Physical activity is a motion that arises due to contraction of skeletal muscles and requires energy. Moderate intensity in doing physical activity is beneficial to reduce the risk of obesity. This is due to the energy that comes out with the incoming balanced (Swift et al., 2014). Physical activity for adults can be done through daily activities such as sweeping, cooking, and purifying the motor not only by exercising (Vuori., 2018). Based on its intensity, physical activity is divided into moderate and vigorous. Vigorous physical activity is 2 times greater than moderate one. While the energy expended at vigorous intensity is more than 6 METs (Metabolic Equivalent Tasks) and physical activity at moderate intensity between 3 - 55.9 METs (Gebel et al., 2015).

The result of physical activity which has been done is a classification factor between vigorous and moderate. Vigorous is an intensity that triggers increased breathing and heart (playing football, jogging, and climbing) in contrast to moderates that increase heart work such as dancing (Physical Activity Guidelines

PJKR

https://jurnal.unimed.ac.id/2012/index.php/jpehr 
for Americans, n.d.). The development of technology causes instantaneous lifestyle changes, such as motorcycles affecting a person's physical activity to walk or cycle, washing machines affect a person's physical activity to wash using brushes, influential video games to have physical habits for teenagers and school age. Independent risk factors of lack of physical activity are death and chronic diseases (WHO, 2013). Furthermore, it can also cause an ideal weight, it can be known by calculating the Body Mass Index (BMI).

Body Mass Index is a barometer to find out a person's weight category. The categories in BMI are skinny, normal, overweight, obesity 1 , and obesity 2 . A good BMI is when the body belongs to the normal category where the weight and high are balance. When an adult male's BMI is $\geq 27$, it is included to obesity but when it is $\geq 25$ and $<27$, it means that it is included in overweight. While adult women's BMI is $\geq 23$ and $<27$, then it is included to overweight (Guidelines for medical nutrition therapy practitioners of Indonesian Ministry of Health, 2018). The bad development of times and lifestyles is very influential on the value of BMI that is classified as obesity. According to (Dayinta et al., 2018), recent year obesity increases significantly. The prevalence of obesity in developed and developing countries reaches 2-4 times. The people deaths cause of obesity reached 3.4 million which cause lots of loss $3.8 \%$. Those results is the number of overweight and obese (The GBD 2013 Obesity Collaboration, 2014). However, overweight can cause health problems such as prediabetes mellitus.

Blood glucose is categorized as prediabtes militus when it is exceeded normal. Blood glucose is divided into low, normal, and high categories. Diabetes mellitus is diagnosed when a person's blood glucose reached from $\geq 126 \mathrm{mg} / \mathrm{dL}$ to $\geq 200 \mathrm{mg} / \mathrm{dL}$. While prediabetes mellitus is diagnosed when a person's blood glucose in a fasting time reached 100-125 mg / dL (IFG) and after doing such a workout, the blood glucose is $140-199 \mathrm{mg} / \mathrm{dL}$. According to Singh et al (2012), $1 / 4$ prediabetes mellitus sufferers are at risk to increase tobe diabetes type 2 , then $1 / 4$ of them is decreased to normal blood glucose and $1 / 2$ of them is stay in the prediabetes. According to the data of International Diabetes Federation (IDF) The population of the world will undergo to 398 million of predibetes millitus sufferers by 2030 . The prevalence of diabetes in Indonesia is $2.6 \%$ in urban areas and $1.4 \%$ in rural areas. While the prevalence of prediabetes mellitus is two times higher and women account for $2.4 \%$ while men are $1.7 \%$ according to Basic Health Research (Riskesdas, 2018). Based on the data above, it can be concluded that it needs more attention and health care.

The increasing number of people with prediabetes mellitus, especially in adolescence between 15 to 18 years, cannot be separated from several factors that cause the disease. Prediabetes mellitus can occur due to high blood glucose, smoking, over 45 years of age, mental burden, lack of activity, BMI, and unhealthy lifestyle (Irianto koes, 2014). Research conducted by (Sukenty et al., 2018) states that these factors can be at risk of developing type 2 diabetes mellitus. While excess weight 7.14 times has a risk for the occurrence of type 2 diabetes mellitus. Being overweight, lack of physical activity and unhealthy

PJKR

https://jurnal.unimed.ac.id/2012/index.php/jpehr 
lifestyle are the biggest factors at risk of becoming diabetes mellitus. Furthermore, in this era of globalization, many teenagers spend more time to play gadgets than going to play or doing other physical activities.

The increasing prevalence of prediabetes mellitus needs to get more attention. Thus, the number of people with diabetes can be reduced. One of the concerns can be done with precautionary measures from an early ages are by knowing the relationship between activities and BMI to the incidence of prediabetes mellitus. Diabetes mellitus is a disease with 3.7 milion people of high mortality, $43 \%$ of deaths happen in developing countries and happen to people at the age of $<70$ years. Therefore, the author tried to dig up information from researches that have been done about prediabetes mellitus and the factors that influence. It is very necessary considering that Indonesia is a densely populated developing country. The sufficient activity is done for 30 minutes in a week and the total is 150 minutes (Riskesdas,. 2018). However, the balance of energy for obesity is the effect of physical activity. The main cause of diabetes type 2, heart disease and stroke is obesity or overweight. According to the U.S. Department of Health and Human Services physical activity guidelines committee (2016) diabetes mellitus and cardiovascular disease are occur when the BMI decreased.

Based on the data above, the researcher is interested to do an in-depth identification related to physical activity and body mass index of prediabetes mellitus. The background of this problem needs to be formulated to answer the question, why physical activity and body mass index need to be identified and how it is related to the occurrence of prediabetes mellitus.

\section{Method}

The research is a literature studies. The research data collection is conducted for 6 months from February to July 2020. The number of articles and journals reviewed as many as 22 journals consisting of quantitative and qualitative journals with related variables namely physical activity, body mass index, and prediabetes mellitus, the sample of this research is high school students aged 15-18 years. In addition, the researcher also sought out key relevant studies in each identified theme to complement the reviews taken, assuming that this would identify additional evidence that has not made it a systematic review. The data searched include Web of Science, PubMed (Medline), CINAHL, OMICS, SocINDEX, BMC and Nature with the following search terms: (Physical activity OR practice OR program OR intervention) and (Body mass index OR obesity OR BMI OR weight loss OR weight management).

Table 1. Journal Reviewed of Phsycal Activity

\begin{tabular}{|c|c|c|c|c|}
\hline No & Author & Method & Result & Conclusion \\
\hline 1. & $\begin{array}{l}\text { (Swift et al., } \\
2014)\end{array}$ & Quantitative & $\begin{array}{l}\text { HIIT Training or CON } \\
\text { produces the increasing of } \\
\text { glycemi control, visceral } \\
\text { adiposity, and aerobic for } \\
\text { prediabetes mellitus sufferers }\end{array}$ & \begin{tabular}{lr} 
physical & \multicolumn{2}{c}{ activity } \\
improves & fitness in \\
prediabetes & mellitus \\
sufferers &
\end{tabular} \\
\hline
\end{tabular}

PJKR

https://jurnal.unimed.ac.id/2012/index.php/jpehr 


\begin{tabular}{|c|c|c|}
\hline 2. & (Vuori., 2018) & $\begin{array}{ll}\text { improving diet and increasing } & \text { physical activity can be } \\
\text { physical activity are effective } & \text { done in daily activities to } \\
\text { ways of reducing death and } & \text { maintain health } \\
\text { disease worldwide } & \end{array}$ \\
\hline 3. & $\begin{array}{l}\text { (Gebel et al., Quantitative } \\
\text { 2015) }\end{array}$ & $\begin{array}{l}\text { doing vigorous activity can lack of physical activity } \\
\text { decrease the risk of death may cause the risk of } \\
\text { until } 9 \% \text { to } 13 \% \\
\text { death }\end{array}$ \\
\hline 4. & $\begin{array}{l}\text { (Physical } \\
\text { Activity } \\
\text { Guidelines } \\
\text { Americans, } \\
\text { n.d.) }\end{array}$ & 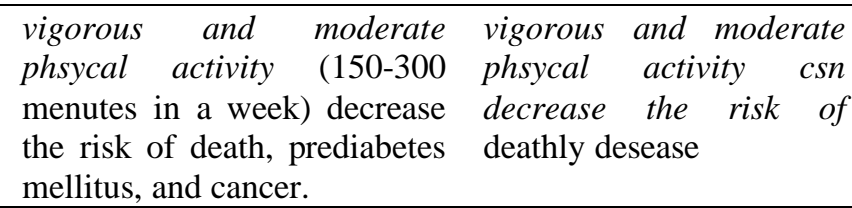 \\
\hline 5. & $\begin{array}{l}\text { (Sari } \& \\
\text { Purnama, 2019) }\end{array}$ & $\begin{array}{lrl}\text { There is a correlation between } & \text { Physical activity which is } \\
\text { phsycal } & \text { activity } & \text { done }<150 \text { menutes in a } \\
\text { towarddiabetes } & \text { melitus }(\mathrm{P} & \text { week risks of prediabetes } \\
\text { value }=0.009 & \text { with } & \text { mellitus } \\
\text { OR }=11.000) & & \end{array}$ \\
\hline 6. & $\begin{array}{l}\text { (Wang et al., Qualitative } \\
\text { 2017) }\end{array}$ & $\begin{array}{l}\text { Physical aktivity in whole } \\
\text { spare time, vigorous, and spare time can decrease } \\
\text { moderate correlate to the the risk of prediabetes } \\
\text { decrease of prediabetes mellitus } \\
\text { mellitus (OR=0.46-0.77) }\end{array}$ \\
\hline 7. & $\begin{array}{l}\text { (Sigal et al., Quantitative } \\
\text { 2018) }\end{array}$ & $\begin{array}{l}\text { physical activity may control Phsycal activity csn be } \\
\text { glucose and lose of weight } \\
\text { the health control of } \\
\text { prediabetes mellitus } \\
\text { sufferer }\end{array}$ \\
\hline 8. & $\begin{array}{l}\text { (Sipayung } \\
\text { Ronika \& } \\
\text { Siregar Fazidah, } \\
\text { 2019) }\end{array}$ & 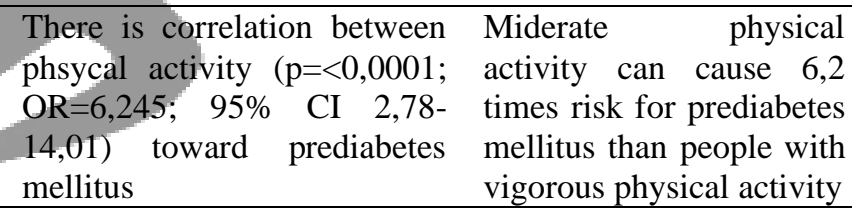 \\
\hline No & Nama Metode & Result $\quad$ Conclusion \\
\hline 1. & $\begin{array}{l}\text { (Al-Zahrani et , Quantitative. } \\
\text { al., 2019) }\end{array}$ & $\begin{array}{ll}\text { Waist sizeand high IMT is found at } & \text { High IMT is the } \\
\text { woman with prediabetes mellitus } & \text { factor } \\
& \text { prediabetes } \\
& \text { mellitus }\end{array}$ \\
\hline 2. & $\begin{array}{l}\text { (Dayinta et al., } \\
\text { 2018) }\end{array}$ & $\begin{array}{l}\text { There is correlation between antara IMT is influenced } \\
\text { phsycal activity, energy intake level, by phsycal activity } \\
\text { protein intake level, carbohidrat } \\
\text { intake leve and fat intake level toward } \\
\text { the nutritional status of children in } \\
\text { school }(\mathrm{p}<0,05)\end{array}$ \\
\hline 3. & $\begin{array}{l}\text { (Sukenty et al., } \\
\text { 2018) }\end{array}$ & $\begin{array}{ll}\text { pradiabetes sufferer is influenced by } & \text { A maintained BMI } \\
\text { Body Mass Index with OR 3,591 (p } & \text { can prevent } \\
\text { value 0,011), dietary habit OR 2,435 } & \text { prediabetes } \\
\text { (p value 0,044), and smoking habit or } & \text { mellitus } \\
\text { passive smoker with OR 2,493 (point } & \\
\text { p 0,046) } & \end{array}$ \\
\hline 4. & $\begin{array}{l}\text { (Saroh et al., Quantitative } \\
\text { 2019) }\end{array}$ & $\begin{array}{l}\text { hypertension, unhealthy diet, BMI } \\
\text { and physical activity are factors of } 7.071 \text { times } \\
\text { greater triggers of }\end{array}$ \\
\hline
\end{tabular}

PJKR

https://jurnal.unimed.ac.id/2012/index.php/jpehr 


\begin{tabular}{|c|c|c|c|c|}
\hline & & & prediabetes mellitus & $\begin{array}{l}\text { prediabetes } \\
\text { mellitus }\end{array}$ \\
\hline 5. & $\begin{array}{l}\text { (Lee et al., } \\
2010)\end{array}$ & Quantitative & $\begin{array}{l}\text { IMT can be controllled by doing } \\
\text { physical activity for about } 60 \text { menitus } \\
\text { in a day. }\end{array}$ & $\begin{array}{l}\text { The increasing of } \\
\text { IMT is caused by } \\
\text { energy and } \\
\text { inbalance output }\end{array}$ \\
\hline 6. & $\begin{array}{l}\text { (Mainous } \\
\text { al., 2016) }\end{array}$ & Quantitative & $\begin{array}{l}\text { Prediabetes mellitus increases in the } \\
\text { age of } 20 \text { and over with healthy } \\
\text { weight is not influenced by } \\
\text { abdominal obesity }\end{array}$ & $\begin{array}{l}\text { IMT is not } \\
\text { influenced by } \\
\text { abdominal obesity }\end{array}$ \\
\hline 7. & $\begin{array}{l}\text { (Vijayakumar } \\
\text { et al., 2019) }\end{array}$ & Quantitative & $\begin{array}{l}\mathrm{BMI} \geq 25 \mathrm{~kg} / \mathrm{m} 2 \text { and the presence of } \\
\text { central obesity is the important } \\
\text { factors of prediabetes mellitus }\end{array}$ & $\begin{array}{l}\text { IMT is the main } \\
\text { factor } \\
\text { prediabetes } \\
\text { mellitus }\end{array}$ \\
\hline
\end{tabular}

Table 3. Journal Reviewed of Prediabetes Mellitus

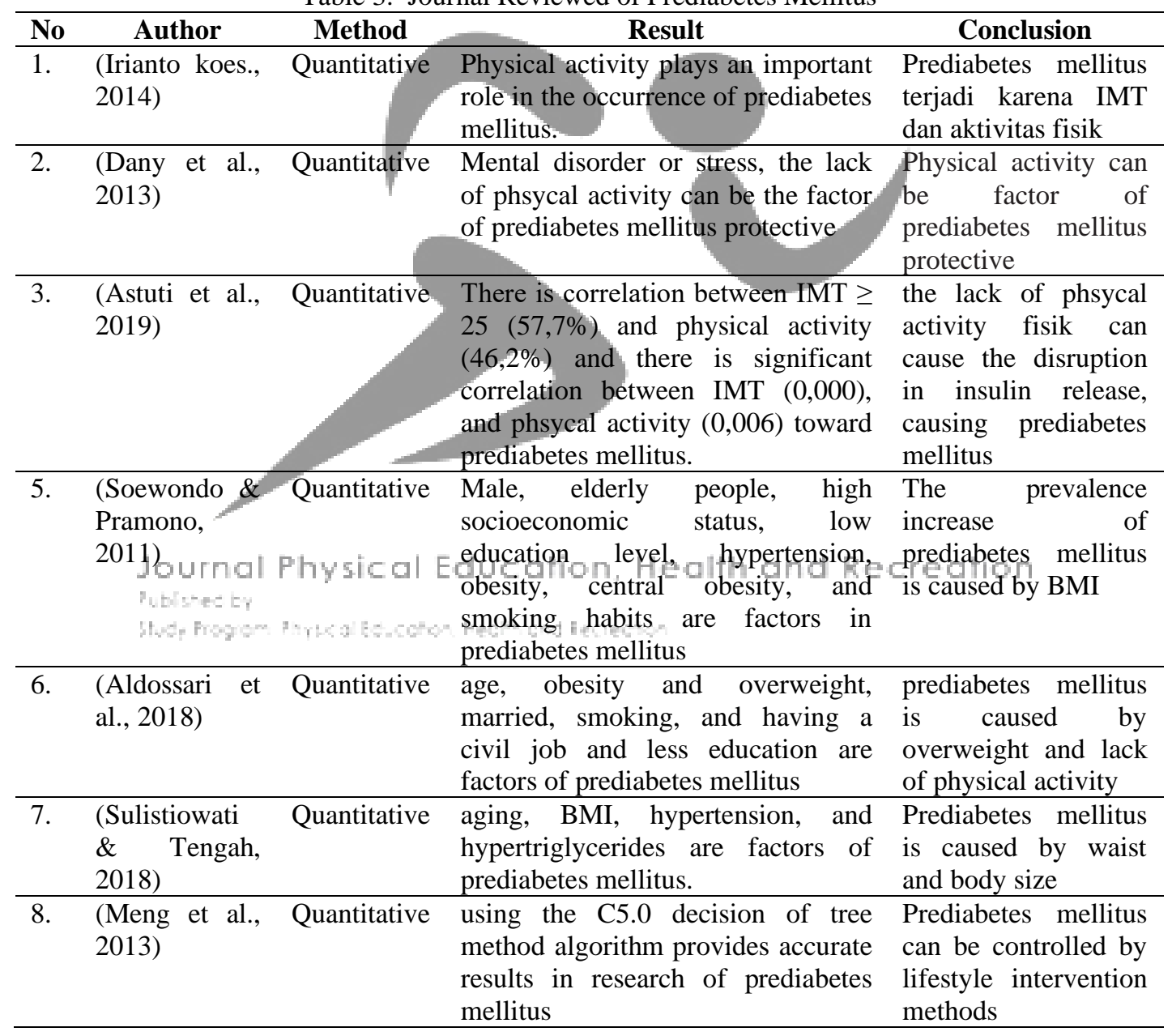

PJKR_

https://jurnal.unimed.ac.id/2012/index.php/jpehr 


\section{Discussion}

Prediabetes mellitus is a person's blood glucose in fasting time is 100-125 $\mathrm{mg} / \mathrm{dL}$ (IFG) and after workout the blood glucose is of $140-199 \mathrm{mg} / \mathrm{dL}$. This cannot be conluded that diabetes mellitus is not eligible (Dany et al., 2013). According to (Astuti et al., 2019) prediabetes mellitus can occur due to the factor of age, overweight and lack of physical activity. In addition, overweight and central obesity are the main factors of prediabetes mellitus (Vijayakumar et al., 2019).

Prevelence of people with prediabetes mellitus is constantly increasing into a serious health problem that must be solved especially in Indonesia. Prediabetes mellitus in Jakarta reached $24.91 \%$ of the number of other diseases (Soewondo \& Pramono, 2011). This is cannot be saparated from the factors that influence the occurrence of prediabetes mellitus such as physical activity and body mass index.

The results of the discussion between articles showed difference results. The researcher has analyzed 22 journals and articles. The 18 journal article is quantitative methods while 4 with qualitative methods related to variable prediabetes mellitus. Other than that, the researeher also analyzed 7 quantitative journal related to diabetes mellitus. The results that BMI is one of the factors of the occurrence of prediabetes mellitus. Therefore, the discussion will be focused on the results of research and differences in results in related articles. However, this research will be focused on the physical activity and body mass index against prediabetes mellitus.

Physical activity

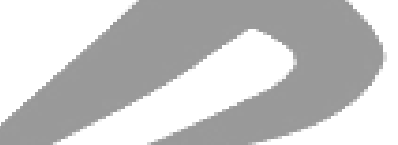

Physical activity of prediabetes seems becomes a protective factor. This can be seen after bivariate analysis on environmental factors such as smoking, foods containing a lot of sugar, coffee, and physical activity (Dany et al., 2013). Therefore, the research by (Sari \& Purnama, 2019) stated that physical activity can cause the risk of prediabetes mellitus. This is because physical activity has a role in controlling glucose from the bloodstream absorbed by muscle glokusa. Physical activity is a core factor to control blood glucose, overweight and reduce mortality by $45-70 \%$ (Sari \& Purnama, 2019). Physical activity can be performed in several levels based on its intensity.

Physical activity is divided into three types namely total, strong and moderate. Physical activity at leisure can be an option for humans to prevent of prediabetes mellitus. Since it was found that activity at leisure both in total, strong, and moderate statistically showed that associated with a decrease in the risk of prediabetes mellitus (OR $=0.46-0.77$ ) (Wang et al., 2017). Easy physical activity can trigger the occurrence of prediabetes mellitus for 6.2 times. Easy physical activity can be even greater risk of prediabetes mellitus by 29,571 times (Sipayung Ronika \& Siregar Fazidah, 2019). This is because the target has not been achieved to perform daily physical activities.

PJKR

https://jurnal.unimed.ac.id/2012/index.php/jpehr 
Physical activity which done for 60 minutes a day can prevent weight gain and BMI in normal condition. Weight gain is caused by an imbalance between energy intake and expenditure (Lee et al., 2010). Physical activity can help diabetics achieve a variety of goals, including improved cardio respiration fitness, increased strength, increased glycemic control, decreased insulin resistance, increased lipid profile, decreased blood pressure (BP) and weight loss maintenance (Sigal et al., 2018). Physical activities such as walking, cycling, jogging, and swimming can be done to provide adequate physical activity (Colberg et al., 2016). Therefore everyone needs to do physical activity in order to feel the benefits.

Activity has good benefits for the human body. Based on journals and articles that have been reviewied show that physical activity has a relationship with the occurrence of prediabetes. These benefits are in line with an article written by (vuori., 2018) that physical activity is beneficial in reducing global mortality and prediabetes. Physical activity performed 150-300 minutes a week can reduce the risk of death, prediabetes mellitus, and cancer. This is because physical activity plays an important role in regulating glucose and regulating the balance of energy entering and exiting the human body. It is necessary to conduct a program to perform physical activities in the community in order to ingrain the habit to do so, so as to reduce the risk of prediabetes mellitus.

Body Mass Index (BMI)

Body Mass Index is a way to find out a person's weight category. The categories in BMI are skinny, normal, overweight, obesity 1 , and obesity 2 . A good BMI is when the body belongs to the normal category or when the weight and height is balanced. When an adult male's BMI is $\geq 27$ it is included to obesity but when the BMI is $\geq 25$ and $<27$, it means that it is included to overweight. When adult women's BMI is $\geq 23$ and $<27$, it means that it includes overweight. (Guidelines for medical nutrition therapy practitioners of the Ministry of Health, 2018). According to Trisnawati and Setyorogo (2016) in (Saroh et al., 2019) older person will weaken mitochondrial performance by $35 \%$. This is due to the reduced physical activity that a person does when entering older age.

Overweight can trigger theprediabetes mellitus. An overweight person is risk of prediabetes mellitus by 7,071 times compared to proportional person (Saroh et al., 2019). According to the journal written by (Al-Zahrani et al., 2019) found that people who suffer from prediabetes mellitus have a high BMI compared to people who do not suffer from prediabetes mellitus. In contrast with the researchby (Mainous et al., 2016), they found that BMI is independently not associated with prediabetes mellitus when taking into account other factors in multivariate. His research was the first to examine the prevalence of prediabetes mellitus among individuals with a normal BMI. Prediabetes are caused by lack of physical activity that affects insulin sensitivity in the body.

Based on the journal article which has been reviewed, it can be concluded that IMT is related to the diabetes mellitus especially for women. IMT in an adult

PJKR

https://jurnal.unimed.ac.id/2012/index.php/jpehr 
woman increases due to the age, married, the lack of physical activity and waist circumference. Therefore, fotr the age of 20 and over, IMT cannot detected that can effect the diabetes mellitus (Mainous,. 2016). This can be found from his research which show that the increase of diabetes prevalence in normal weight and IMT. Based on his research, weist circumference gives more effect in diabetes mellitus. Unhealthy weist circumference is $>102 \mathrm{~cm}$ for men and $>88 \mathrm{~cm}$ for women. The research in line with the research done by (sulistiwati \& tengah,. 2018). They found that weist circumference can be the factor of diabetes mellitus. However, IMT is the factor of diabetes mellitus when it followed by weist circumference in the adult.

\section{Prediabetes Mellitus}

The prevalence of prediabetes in the South Asian is dominated by those who live in the city than in village. Some characteristics such as high BMI, Overweight and lack of physical activity are high factors for prediabetes mellitus. People tend to do daily activities with a short time that eventually becomes a habit among the community. The habit effect the weight over a period of several years. In addition, the consumption of vegetables can decrease the factor of prediabetes mellitus. This can happen in adults who do less physical activity. (Aldossari et al., 2018).

The prediabetes mellitus sufferer is faced by people in the age around to 45 year old. Sufferers of female prediabetes mellitus are more numerous than men. This is because women have a BMI and a larger weist ircumference (Sulistiowati \& Central, 2018). Age, occupation, smoking habits and level of education can be factors in the occurrence of prediabetes. Contrast to the research by (Dany,. 2013), he found that BMI is the protective factor of prediabetes mellitus.

Based on journals and articles that have been reviewed, it can be concluded that prediabetes mellitus can occur due to several things including age, occupation, level of education, smoking habits, especially physical activity and BMI. This means that the result is contrast to the research by (Dany,. 2013) which conclude that BMI is a protective factor of prediabetes mellitus. The last, this only a difference of point of view from researchers in mentioning the risk factors for the occurrence of prediabetes mellitus.

Therefore it is necessary to develop a habit in the community to do 150-300 minutes of activity a week so that BMI in the body is controlled. The ingrained habit of doing physical activity will affect BMI control because physical activity acts as a balance between incoming and outgoing energy in the human body. So this can be a preventive step in the occurrence and growth of the prevalence of prediabetes. Further research is needed on accurate methods in conducting research on the occurrence of prediabetes, one of which is by using lifestyle intervention methods (Meng et al., 2013).

\section{Conclusion}

Based on the results that has been done, it can be concluded that physical activity and BMI are not the main factors of prediabetes, there are other factors

PJKR_ 
that influence the occurrence of prediabetes mellitus. Physical activity plays a role in controlling blood glucose, the balance energy which come and out from the body. Activities is important role in the body towards the increase of BMI and the occurrence of prediabetes mellitus. BMI can be a factor of prediabetes if it followed by unhealthy waist circumference, where the number is waist circumference $>102 \mathrm{~cm}$ for men and $>88 \mathrm{~cm}$ in women. People with lack of physical activity will have increasing of BMI, if it becomes a habit then the BMI will be increased and uncontrolled then caused of prediabetes mellitus.

\section{References}

AHA Scientific Position. Risk factors and coronary heart disease. Diakses 4 Maret 2020 dari www.americanheart.org/presenter.jhtml/identifier=4726

Al-Zahrani, J. M., Aldiab, A., Aldossari, K. K., Al-Ghamdi, S., Batais, M. A., Javad, S., Nooruddin, S., Zahid, N., Razzak, H. A., \& El-Metwally, A. (2019). Prevalence of Prediabetes, Diabetes and Its Predictors among Females in Alkharj, Saudi Arabia: A cross-sectional study. Annals of Global Health, 85(1), 1-13. https://doi.org/10.5334/aogh.2467

Aldossari, K. K., Aldiab, A., Al-Zahrani, J. M.,-Al-Ghamdi, S. H., Abdelrazik, M., Batais, M. A., Javad, S., Nooruddin, S., Razzak, H. A., \& El-Metwally, A. (2018). Prevalence of Prediabetes, Diabetes, and Its Associated Risk Factors among Males in Saudi Arabia: A Population-Based Survey. In Journal of diabetes research (Vol. 2018, hal. 2194604). https://doi.org/10.1155/2018/2194604

Astuti, A., Studi, P., Keperawatan, I., Tinggi, S., Kesehatan, I., \& Ibu, H. (2019). Usia, Obesitas dan Aktifitas Fisik Beresiko Terhadap Prediabetes. 4(2), 319-324.

Colberg, S. R., Sigal, R. J., Yardley, J. E., Riddell, M. C., Dunstan, D. W., Dempsey, P.C., Horton, E. S., Castorino, K., \& Tate, D. F. (2016). Physical activity/exercise and diabetes: A position statement of the American Diabetes Association. Diabetes Care, 39(11), 2065-2079. https://doi.org/10.2337/dc16-1728

Dany, F., Kusumawardani, N., Pradono, J., Kristianto, Y., Penelitian, P., Dasar, T., Penelitian, P., \& Daya, S. (2013). Faktor Risiko Prediabetes: Isolated Impaired Fasting Glucose ( $i$-IFG ), Isolated Impaired Glucose Tolerance ( i-IGT ) dan Kombinasi IFG-IGT ( Analisis Lanjut Riskesdas 2013 ). 113124.

Departemen Kesehatan Republik Indonesia.Laporan Nasional Riset Kesehatan Dasar (RISKESDAS) 2018.Jakarta: Badan Penelitian dan Pengembangan Kesehatan; 2018

Dayinta, N., Ermona, N., \& Wirjatmadi, B. (2018). Hubungan Aktivitas Fisik Dan Asupan Gizi Dengan Status Gizi Lebih Pada Anak Usia Sekolah Dasar Di Sdn Ketabang 1 Kota Surabaya Tahun 2017 Relationship between Physical Activity, Nutrition Intake and Overweight Status among Elementary School Student in SDN. Amerta Nutrition, 2(1), 97-105. 
https://doi.org/10.20473/amnt.v2.i1.2018.97-105

Gebel K, Ding D, Chey T, Stamatakis E, Brown WJ, Bauman AE. Effect of Moderate to Vigorous Physical Activity on All-Cause Mortality in Middleaged and Older Australians [published correction appears in JAMA Intern Med. 2015 Jul;175(7):1248]. JAMA Intern Med. 2015;175(6):970-977. doi:10.1001/jamainternmed.2015.0541

Physical Activity Guidelines for Americans. (n.d.).

IRIANTO, Koes (Pengarang).Epidemiologi Penyakit Menular Dan Tidak Menular : Panduan Klinis / Koes Irianto .2014. http://perpus.bandungkab.go.id/opac/detail-opac?id=6490

Lee, I. M., Djoussé, L., Sesso, H. D., Wang, L., \& Buring, J. E. (2010). Physical activity and weight gain prevention. JAMA - Journal of the American Medical Association, 303(12), 1173-1179. https://doi.org/10.1001/jama.2010.312

Mainous, A. G., Tanner, R. J., Jo, A., \& Anton, S. D. (2016). Prevalence of prediabetes and abdominal obesity among healthy-weight adults: 18-year trend. Annals of Family Medicine, 14(4), 304-310. https://doi.org/10.1370/afm.1946

Meng, X., Huang, Y., Rao, D., Zhang, Q., \& Liu, Q. (2013). Comparison of three data mining models for predicting diabetes or prediabetes by risk factors. Kaohsiung Journal of Medical Sciences, 29(2), 93-99. https://doi.org/10.1016/j.kjms.2012.08.016

Clutterbuck, D., Asboe, D., Barber, T., Emerson, C., Field, N., Gibson, S., Hughes, G., Jones, R., Murchie, M., Nori, A. V, Rayment, M., Sullivan, A., Savolainen-Kopra, C., Liitsola, K., Isojärvi, J., Lindeman, J., Kontio, M., Mäkelä, M., ... Cook, H. (2019). The sexual health and wellbeing of vulnerable groups in Scotland: International Journal of Environmental Research and a Public Health, and R(May), Hertion 14-18. https://doi.org/10.4103/jnsbm.JNSBM

Sipayung Ronika, Siregar Fazidah, N. (2019). Hubungan Aktivitas Fisik Dengan Kejadian Diabetes Melitus Tipe 2 Pada Perempuan Usia Lanjut Di Wilayah Kerja Puskesmas Padang Bulan Medan Tahun 2017. Jurnal Muara Sains, Teknologi, Kedokteran, dan Ilmu Kesehatan, Vol. 2, No, 78-86.

Sari, N., \& Purnama, K. A. (2019). Aktivitas Fisik dan Hubungannya dengan Kejadian Diabetes Melitus. 2(4), 368-381.

Saroh, B., Universitas, M., \& Malang, N. (2019). Hubungan Antara Faktor Risiko Diabetes Melitus yang Dapat Diubah Dengan Kejadian DM Tipe 2 di Puskesmas Janti Kota Malang. 1(1), 59-71.

Sigal, R. J., Cep, M. J. A., Bacon, S. L., Boulé, N. G., Dasgupta, K., Kenny, G. P., \& Riddell, M. C. (2018). Physical Activity and Diabetes Diabetes Canada Clinical Practice Guidelines Expert Committee. 42, 54-63.

Soewondo, P., \& Pramono, L. A. (2011). Prevalence, characteristics, and predictors of pre-diabetes in Indonesia. Medical Journal of Indonesia, 20(4), 283-294. https://doi.org/10.13181/mji.v20i4.465

PJKR

https://jurnal.unimed.ac.id/2012/index.php/jpehr 
Sukenty, N. T., Shaluhiyah, Z., \& Suryoputro, A. (2018). Faktor Perilaku dan Gaya Hidup yang Mempengaruhi Status Prediabetes Pasien Puskesmas Pati II. 13(2).

Sulistiowati, E., \& Tengah, B. (2018). Perkembangan Diabetes Melitus Tipe 2 dari Prediabetes di Bogor, Jawa Barat Progression of Type 2 Diabetes Mellitus from Prediabetes at Bogor, West Java. 2(1), 59-69.

Swift D.L., Johannsen N.M., Lavie .J., Earnest C.P. and Church T.S. (2014). The Role of Exercise and Physical Activity in Weight Loss and Maintenance. Prog Cardiovasc Dis. 56(4): 441-447.

US Department of Heath \& Human Services. (2016). Physical activity guideline for Americans.Diakses4 november 2019 darihttp://www.health.gov/paguidelines/chapter4.aspx

Vijayakumar, G., Manghat, S., Vijayakumar, R., Simon, L., Scaria, L. M., Vijayakumar, A., Sreehari, G. K., Kutty, V. R., Rachana, A., \& Jaleel, A. (2019). Incidence of type 2 diabetes mellitus and prediabetes in Kerala, India: Results from a 10-year prospective cohort. In BMC Public Health (Vol. 19, Nomor 1). https://doi.org/10.1186/s12889-019-6445-6

Vuori, I. (2018). World Health Organization and Physical Activity. Progress in Medicine, $3(1)$ $\mathrm{e} 0012$. https://doi.org/10.1097/pp9.0000000000000012

Wang, J., Wu, Y., Ning, F., Zhang, C., \& Zhang, D. (2017). The Association between Leisure-Time Physical Activity and Risk of Undetected Prediabetes. Journal of Diabetes Research, 2017. https://doi.org/10.1155/2017/4845108

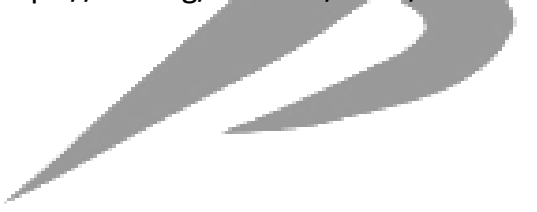

Journal Physical Education. Health and Recreation

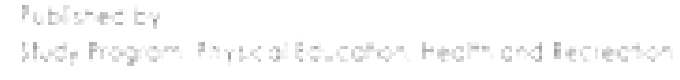

